\title{
The Green New Deal, Financial Statements and the Accounting Profession
}

\author{
Dr. Sunita Rao \\ School of Business, Washburn University, Topeka, Kansas, USA \\ *Correspondence: Dr. Sunita Rao, Email: sunita.rao@washburn.edu
}

\begin{abstract}
Climate change is real and immediate. The Green New deal (GND) is a set of policies, measures, events and actions designed to bring about systemic change to counter the effects of the catastrophic effects of climate change. These policies, measures, events and actions will deeply impact the accounting profession and the financial statements, since it aims to transform the US economy in a sustainable way by focusing on the long term. This article discusses the effects of GND on financial reporting and disclosure.
\end{abstract}

Keywords: Green new deal, GND, Financial statements, Accounting, Impact of GND on accounting

\section{ARTICLE INFORMATION}

Author(s): Dr. Sunita Rao

Received: 25 Jan, 2021; Accepted: 09 Mar, 2021; Published: 19 Mar, 2021;

e-ISSN: 2347-4696;

Paper Id: BMN-IJBMR-2021-13;

Citation: doi.org/10.37391/IJBMR.090113

Webpage-link:

https://ijbmr.forexjournal.co.in/archive/volume-9/ijbmr-090113.html

\section{INTRODUCTION}

"The real focus in quarterly reporting is the earnings conference call. The problem with earnings conference calls is we get into short termism, which is not the way that business models are done. They are done on a long-term basis."

-Bob Laux, region lead for North America at the International Integrated Reporting Council at the 16th annual Baruch College Financial Reporting conference

Corporate short termism means focusing on short term profits regardless of the impact on the company's future. In this article, I will discuss how the passage of proposed legislation on the Green New Deal (GND) will, in general, change the focus of financial reporting, and in particular, make it focus on the long-term. The article will also discuss how it will impact the accounting profession. The concept behind the GND has been appealing for a while [1-3]. Because of the current planetary emergency, narratives about climate change have intensified, and adapting some form of legislation along the lines of the GND is highly likely. A paradigm like the GND will encourage the modification of disclosure frameworks, such as the US Generally Accepted Accounting Principles (GAAP), since it aims to transform the US economy in a sustainable way by focusing on the long term. The GND aims at wide structural changes for the US economy, its infrastructure development, and its social landscape. Many companies will see the GND requirements as an opportunity to streamline their operations and become profitable under a new dominant paradigm. In this context, the following quote by the Governor of the Bank of England is especially pertinent:

"There will be industries, sectors and firms that do very well during the process of transitioning needed to tackle the climate-crisis, because they will be part of the solution. But there will also be ones that lag behind and they will be punished. Companies that don't adapt will go bankrupt without question."

-Mark Carney, Governor, Bank of England, in an interview with The Guardian on October 13, 2019

About two weeks ago, AP News [4] reported that "EU lays out 1 trillion-euro plan to support Green Deal." All of these indicate the Green New Deal is a mainstream issue in major economies in the world.

\section{BACKGROUND}

A special report on global warming by the Inter-Governmental Panel on Climate Change (IPCC) and the 4th National Climate Assessment found that there has been an increase in global warming by 1.5 degrees Celsius in the past 35 years, and that human activity is the cause of this increase. They also documented catastrophic effect of climate change and projected that at the current rate, it will engender mass migration and loss of trillions of dollars in economic output every year. The IPCC recommended the global reduction of greenhouse gas emissions from human sources from $40 \%-60 \%$ of 2010 levels by the year 2030, and net zero global emissions by 2050 . Along the lines of the IPCC findings, the GND also details the crises that the US is currently experiencing related to climate change. This calls for drastic changes like those noted by Mark Carney above. Sweeping changes were made in the US during the time of President Franklin D Roosevelt in the 1930s that brought about the New Deal, a paradigm that dramatically removed the country from the Great Depression and made it a world leader $[5,6]$.

The GND aims to reduce greenhouse gas emissions and meet the power demand of the US by harnessing clean and renewable zero-emission energy sources by 2030 (page 3 of the legislation). In fact, support for goals like the GND's was voiced recently by a group of some of the $21^{\text {st }}$ century's top CEOs, called the Business Roundtable. This group of CEOs, including leaders of companies like Apple, Walmart, Amazon, 
and Bank of America, "broke corporate orthodoxy" by issuing a statement that said "....the purpose of a corporation should no longer advance only the interests of shareholders. Instead, they must also invest in their employees, protect the environment and deal fairly and ethically with their suppliers" [7].

\section{LITERATURE REVIEW}

Recently, some studies have focused on the GND. In addition to Barbier discussed above, Pettifor [8] makes a compelling case for the GND by pointing out that "the United Nations' Intergovernmental Panel on Climate Change (IPCC) issued a call for action in 2018 and circulated widely that annual global emissions need to be cut by half and hit net zero carbon by the middle of the $21^{\text {st }}$ century." Naomi Klein [9] takes this argument further by emphasizing that "capitalism needs significant change to the existing economic structure". Aronoff, et al., [10] also highlight this point of requiring action from all social groups to tackle the problem to climate change and social inequalities. Mastini, et al., [11] discuss ways to fund the GND and point out that it is not necessary for the GND to stimulate GDP growth or depend on it for financing.

While the above studies are significant, none of them analyze the impact of GND policies on any profession or group. This article addresses the important question of what such a change will mean to the accounting profession and financial statements, and, how these will change in response to the GND.

The article will now discuss the GND's impact on financial statements. It will illustrate some of the changes that would likely happen, were this legislation to be passed. For this purpose, here are two measurement models:

$$
\begin{aligned}
& \mathscr{E} \text { on } \mathrm{F}= f(\mathrm{~B}, \mathrm{I}, \mathrm{N}, \underline{\mathrm{R}}), \\
& \text { Where, }, \mathscr{E}=\text { Effect } \\
& f=\text { function of } \\
& \mathrm{F}=\text { Financial Statements, } \\
& \mathrm{B}=\text { Balance Sheet } \\
& \mathrm{I}=\text { Income Statement } \\
& \mathrm{N}=\text { Footnotes } \\
& \\
& \underline{\mathrm{R}}=\text { Retained Earnings }
\end{aligned}
$$

$\mathscr{E}$ on $\mathrm{A} / \mathrm{P}=\mathrm{g}(\mathrm{A} / \mathrm{P} \mathscr{L}, \mathscr{R}, \mathrm{P})$,

Where, $\mathscr{E}=$ Effect

$\mathrm{g}=$ function of

A/P $\mathscr{L}=$ Accounting Profession at Large

$\mathscr{R}=\mathrm{GND}$ and the Regulators

$p=$ GND and the preparers of the Financial

Statements

These are elaborated below:

\section{THE IMPACT OF GND ON FINANCIAL STATEMENTS}

In analyzing the data, the focus was on identifying the most common themes that would help the researcher gain better insights into the experiences of the participants. These included: motive for immigration; challenges as experienced by the participants in the UK and reasons behind mothers' preference for sating at home.

\subsection{Balance Sheet}

The implementation of the GND requires that accounting personnel work with environmental, social, and governance experts in their company to identify and value their associated risks, respectively. These values will appear in the balance sheet in the form of allowances and reserves.

GND compliance will also require companies to buy sustainably sourced materials and have suppliers that use sustainable practices. Such requirements will lead to inventories of raw materials (and in-turn work-in-process and finished goods) that have higher monetary values because of higher operational costs. On the other hand, the GND will offer incentives to companies that demonstrate adequate progress towards its goals. One of those incentives will be tax breaks. This will lead to lower taxes in general, and to defer taxes in particular.

\subsection{Income Statement}

The article will begin its analysis with revenues and explore various expenses, starting with cost of sales. Companies will be eager to make as much income from operations as they had before the passing of the Green New Deal. Since the GND emphasizes environmental benevolence, products will become more environmentally friendly in the long term. Companies will not only benefit from the increased revenues from sales, but also from safe disposal of their products. This will help compensate for the capital expenditures required, and the resulting increase in depreciation, in order to comply with the new GND requirements. Innovative companies will also have higher revenue figures as they develop new products and new markets, which will offset higher salaries and wages.

Companies that demonstrate adequate progress towards GND goals will experience higher cost of sales due to higher cost of materials and higher labor costs; however, as pointed out in the previous section, they will pay lower income taxes, and therefore make lower provisions for income taxes. Furthermore, interest expenses to be paid to banks will be lower when companies show adequate progress towards GND goals.

Higher operating expenses will not necessarily result in loss, as illustrated by Cisco Systems Inc., one of the country's largest technology companies. Cisco has a well-developed social responsibility strategy, and its focus is to develop and market products that are meant to be refurbished, reused, and then recycled [12]. This strategy not only eliminates waste, but also saves time, effort, and money on making new products. 
Cisco has benefitted from this strategy, experiencing a \$6 billion increase in its revenue and a $\$ 4$ billion increase in its net income since 2014.

\subsection{Financial Statement Footnotes}

The nature of footnotes related to accounting policies, reserves, assets, and liabilities will vary with industry and size. Companies in some industries have a larger social and environmental footprint than those in other industries. Larger companies also have greater resources at their disposal, and thus will find that fulfilling their requirements for the GND will be easier.

One of the goals of the GND is to bring greenhouse gas emissions down to net-zero and meet $100 \%$ of the power demand in the US through clean, renewable, and zeroemission energy sources by 2030 . The goal discussed above will require companies to disclose their current greenhouse emissions and how they plan to reduce them over both the next accounting cycle as well as over a longer time horizon. Companies will need to disclose how they are already using clean and renewable energy, or how they might be replacing their current energy sources with clean and renewable energy sources.

The paper discussed the two primary sources of greenhouse gas emissions in the US; namely, the transportation sector and the electricity production sector [13]. As such, the goals related to greenhouse gas emissions will have an increased effect on companies in these sectors. These companies will have to pay particular attention to their footnote disclosures because they will need to reveal how they are working with the US government to reduce their greenhouse gas emissions. This will be part of a long-term plan, since reduction of greenhouse gas emissions usually takes a few years. Such plans will have to be revealed by companies in their financial statement footnotes.

The GND also calls for the creation of millions of jobs to provide a job guarantee to all Americans, along with access to nature, clean air and water, healthy food, a sustainable environment, and community resiliency. The Management Discussion and Analysis (MD\&A) section is the best place for a company to disclose their efforts towards achieving these goals in the current year, and how far they have progressed towards their long-term goals.

The GND also involves tackling the issues associated with social and economic inequality. This is due to the fact that the gap between the wealthiest and poorest US citizens has been the largest since the $1920 \mathrm{~s}$. Corporations are an important part of the economic machinery in the US and will be called upon to work with the government to reduce this gap. Therefore, as part of the GND, corporations will be required to disclose what they are doing to combat social and economic inequality. Moreover, companies will disclose their efforts over the past year to treat employees equitably and how their progress stacks up against their long-term plans.

\subsection{Retained Earnings}

Retained earnings are the cumulative earnings of a company after paying out dividends. Companies will be interested in maintaining or growing their retained earnings compared to those before GND passage. While some companies' resources will be used to provide for adherence to the GND requirements, retained earnings are likely to grow in the long term because of the aforementioned increases in revenue. Additionally, since the products will be environmentally friendly, allow for safe disposal, and stakeholders are treated fairly, the number of lawsuits will likely be significantly reduced.

The items 4.1 through 4.4 above show that businesses will realize that the GND goals they have set for themselves obtaining sustainably sourced materials, doing business with suppliers who adopt sustainable practices, taking advantage of tax breaks, paying workers appropriate wages, reducing current greenhouse gas emissions, assessing their climate change impact, developing new products, and exploring new markets - will take longer than a single year to achieve. This will in turn make them think about their long-term goals, rather than their next quarter profits, thus shifting business' focus from the short term to the long-term.

\section{A FEW EXAMPLES TO ILLUSTRATE THE IMPACT OF GND ON THE ACCOUNTING PROFESSION 5.1 Impact on the Accounting Profession at Large \\ The GND will bring about a variety of changes to the accounting profession. The accountants employed by both small and large businesses in the areas of product costing and pricing, budgeting, and the examination of investment alternatives will have to focus on the requirements and costs of compliance. Teams of people, including accountants, in both small and large companies will have to make assessments about which requirements apply to them and how to meet them. This will provide opportunities to learn new skills and expand their horizons.}

GND compliance is not merely the job of accountants, seeing as internal controls are the responsibility of the Board, management, internal auditors, and accountants combined. As such, all of them will be involved in the design of a plan and install controls to ensure that their company becomes GND complaint. Accounting personnel and financial managers will be responsible for implementing GND requirements. Certified Public Accountants (CPAs) who examine the underlying transactions and systems of a company will have to ensure GND compliance in design, installation, and implementation. Furthermore, when they provide an independent report on the fairness of the financial statements, they will have to express an opinion on the company's GND compliance. 


\section{Business and Management Research (IJBMR)}

Research Article | Volume 9, Issue 1 | Pages 88-92 | e-ISSN: 2347-4696

\subsection{GND and the Regulators}

The work of standard setters and regulators, such as the Financial Accounting Standards Board (FASB), the Securities and Exchange Commission (SEC), the Public Company Accounting Oversight Board (PCAOB), and the American Institute of Certified Public Accountants (AICPA) will be influenced by the GND's goals. As these goals will take time and effort to achieve, the GND will provide standard setters with general targets that have a long-term focus. This, in turn, will help them make guidelines and rules that are geared towards long-term sustainable performance. Accountants who are employed in regulating institutions (for example, the SEC, the FASB, the PCAOB, or the AICPA) will have to carefully think through the requirements of the GND and set guidelines, as well as modify GAAP and auditing standards.

According to de Pee, et al., cutting industry's carbon emissions will require significant investment and coordinated effort among businesses, governments, and other stakeholders [14]. Item (D) on Page 11 of the GND document, lines 13-15 [15], will spur regulators to require a dollar amount of funds that a publicly listed company has spent on R\&D of new clean and renewable energy technologies. Lines $16-25$ of Item (E) on page 11 will motivate regulators to make it mandatory for companies to reveal the amount of funds that they have spent on the development of local and regional economies and how they have contributed to building wealth and community ownership.

\subsection{GND and the Preparers of the Financial Statements}

GND disclosure requirements will also compel financial statement preparers to catalog carbon footprints, transparency about abandoned waste sites, and methods of waste disposal. The GND compliance and disclosure requirements will help financial statement preparers, users, and marketers better understand companies' exposure to climate change risks, as well as their ability to continue their activities in the future, thus affecting peoples' lives all around the globe. Climate change is an issue of extreme urgency and has already started affecting the planet. As a 2019 New York Times article illustrated, "people are roasting alive in California towns hit by the deadliest wildfires in the state's history. Midwestern cities are reeling from deluge upon deluge. Coastal communities are starting to drown from a relentlessly rising sea [16]." Understanding the risks associated with climate change is crucial for companies, considering that over the past decade, the US federal government spent $\$ 350$ billion as a result of extreme weather conditions and fire events [17], and economic losses are expected to be more than $\$ 500$ billion by the year 2100 [18]. Sooner or later, it will become imperative for companies in the US to embrace GND requirements. This will surely impact how the financial statements are prepared, some of which is articulated above.

\section{CONCLUSION}

The proposed GND, or some modified version of it, is likely to become a reality in the United States, and its impact on the accounting profession will be significant. The accounting profession will come into more prominence due to fact that accountants, auditors, and managers alike will play a significant role in GND implementation, as it comprises vast regulatory changes that will change how disclosures are viewed and prepared. The qualitative and quantitative aspects of 10-Q and 10-K filings will undergo such changes as noted. Because of new GND requirements, standard setters and regulators like the SEC, FASB, AICPA, and GASB will have an expanded role in the government and society at large. The GND will be a boon for the accounting profession, bringing in enormous opportunities for accountants. The auditing profession too will undergo major changes, providing boundless opportunities to train auditors in new skills, such as auditing carbon footprints and assessing climate change impacts, in addition to the classical notions of auditing. The companies who start early and prepare for the anticipated changes will be ahead in the game and will demonstrate that they care about the future of both the economy and society, and that they are willing to contribute towards the transformation of the US economy.

\section{REFERENCES}

[1] Barbier, E. (2010) How is the Global Green New Deal going? Nature, 464 (7290): 832-833.

[2] Barbier, E. B. (2010b) A global green new deal: Rethinking the economic recovery: Cambridge University Press.

[3] Barbier, E. B. (2019) How to make the next Green New Deal work. Nature, 565 (7737): 6.

[4] AP News. (2020) EU lays out 1 trillion-euro plan to support Green Deal.

[5] Billington, R. A., and M. Ridge. (1981) American history after 1865. Maryland, US: Rowman \& Littlefield.

[6] Clements, P. (2008) Prosperity, Depression and the New Deal: Hodder Education.

[7] Gelles, D., and D. Yaffe-Bellany (2019) Shareholder Value Is No Longer Everything, Top C.E.O.s say. The New York Times.

[8] Pettifor, A. (2020) The Case for the Green New Deal. New York, US: Verso Books.

[9] Klein, N. (2020) On Fire: The (Burning) Case for a Green New Deal. New York, US: Simon \& Schuster.

[10] Aronoff, K., A. Battistoni, D. A. Cohen, and T. Riofrancos. (2019) A Planet to Win: Why we need a Green New Deal. New York, US: Verso Books.

[11] Mastini, R., G. Kallis, and J. Hickel. (2021) A Green New Deal without growth? Ecological Economics, 179: 1-9.

[12] Cisco 2017 CSR Report. (2017) 2017 Corporate Social Responsibility Report: Accelerating Global Problem Solving.

[13] Environmental Protection Agency (EPA). (2019) Sources of Greenhouse Gas Emissions.

[14] de Pee, A., D. Pinner, O. Roelofsen, K. Somers, E. Speelman, et al. (2018) How industry can move toward a low-carbon future. McKinsey \& Company. 
[15] https://www.congress.gov/116/bills/hres109/BILLS116hres109ih.pdf

[16] Gillis, J. (2019) The Democratic Party is trying to Downplay Climate Change. Don't Let It. The New York Times.

[17] https://www.gao.gov/assets/690/687466.pdf

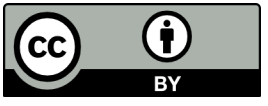

Commons

(C) 2021 by the Dr. Sunita Rao. Submitted for possible open access publication under the

terms and conditions of the Creative

(http://creativecommons.org/licenses/by/4.0/).

[18] https://www.investopedia.com/the-green-new-deal-explained4588463 